\title{
Mass loss from an ice-sheet drainage basin in West Greenland
}

\author{
Morten L. Andersen, Signe B. Andersen, Lars Stenseng, Henriette Skourup, William Colgan, Steen \\ S. Kristensen, John P. Merryman Boncori, Andreas P. Ahlstrøm, Xavier Fettweis, René Forsberg, \\ Michele Citterio, Jason E. Box, Dirk van As and Robert S. Fausto
}

The Greenland ice sheet is losing mass to the ocean at an increasing rate (Thomas et al. 2006). During the 1980s the ice sheet was believed to be in near-equilibrium (van den Broeke et al. 2009). Within the first decade of the 21 st century, however, a net negative balance was observed. Greenland's present rate of ice loss is $c .250 \mathrm{Gt} \mathrm{yr}^{-1}$, equivalent to a sea-level rise contribution of $c .0 .69 \mathrm{~mm} \mathrm{yr}^{-1}$. The rate of ice loss has increased over the post 1992 observation period (Shepherd et al. 2012).

The ice-sheet mass budget can be partitioned into two main components: (1) surface mass balance (SMB; the net difference between accumulation and surface ablation) and (2) marine ice loss $(D$; iceberg discharge via glacier dynamics plus subsurface melt at the glacier terminus). Over the past decade, the surface mass-balance proportion has accelerated relative to the $D$ component, changing from $c .50 \%$ in 2000-2008 (van den Broeke et al. 2009) to more than two thirds (68\%) in 2009-2012 (Enderlin et al. 2014).

Whereas modern climate models appear to capture the surface mass-balance response to climate change, the physical processes driving variability in glacier discharge are more complex. Recent increases in $D$ may be due to: (1) changing force-balance at the ice-ocean interface as suggested by model simulations (e.g. Nick et al. 2009, 2013), (2) changing basal lubrication at the ice-bed interface due to increased meltwater availability (Zwally et al. 2002; Andersen et al. 2010), and/or (3) decreasing ice viscosity due to increasing ice temperature (van der Veen et al. 2011). The high spatial variability in these forcing mechanisms and a large sensitivity to local fjord geometry (Nick et al. 2013) require basin scale studies of glacier dynamics to elucidate local causes of glacier acceleration.

In 2007 the Programme for Monitoring the Greenland Ice Sheet (PROMICE) was initiated to gain insight into the changing mass balance of the Greenland ice sheet using quantitative meteorological observations, as well as airborne surveys of ice thickness and flow-velocity observations (Ahlstrøm et al. 2008). Here we present the first calculations of ice discharge using PROMICE observations, with focus on a West Greenland ice-sheet drainage basin previously defined as 'Basin 7' (Zwally et al. 2012; Fig. 1). The c. $400 \mathrm{~km}$ long ice-sheet margin within Basin 7 includes the $6 \mathrm{~km}$ wide Jakobshavn Isbræ, and several other marine-terminating outlet glaciers, such as Store Gletscher and Rink Isbræ (Figs 1,2). We combine satellite-derived, ice-surface velocities, airborne ice-thickness measurements, and modelled surface mass balance to assess the dynamic discharge from Basin 7.

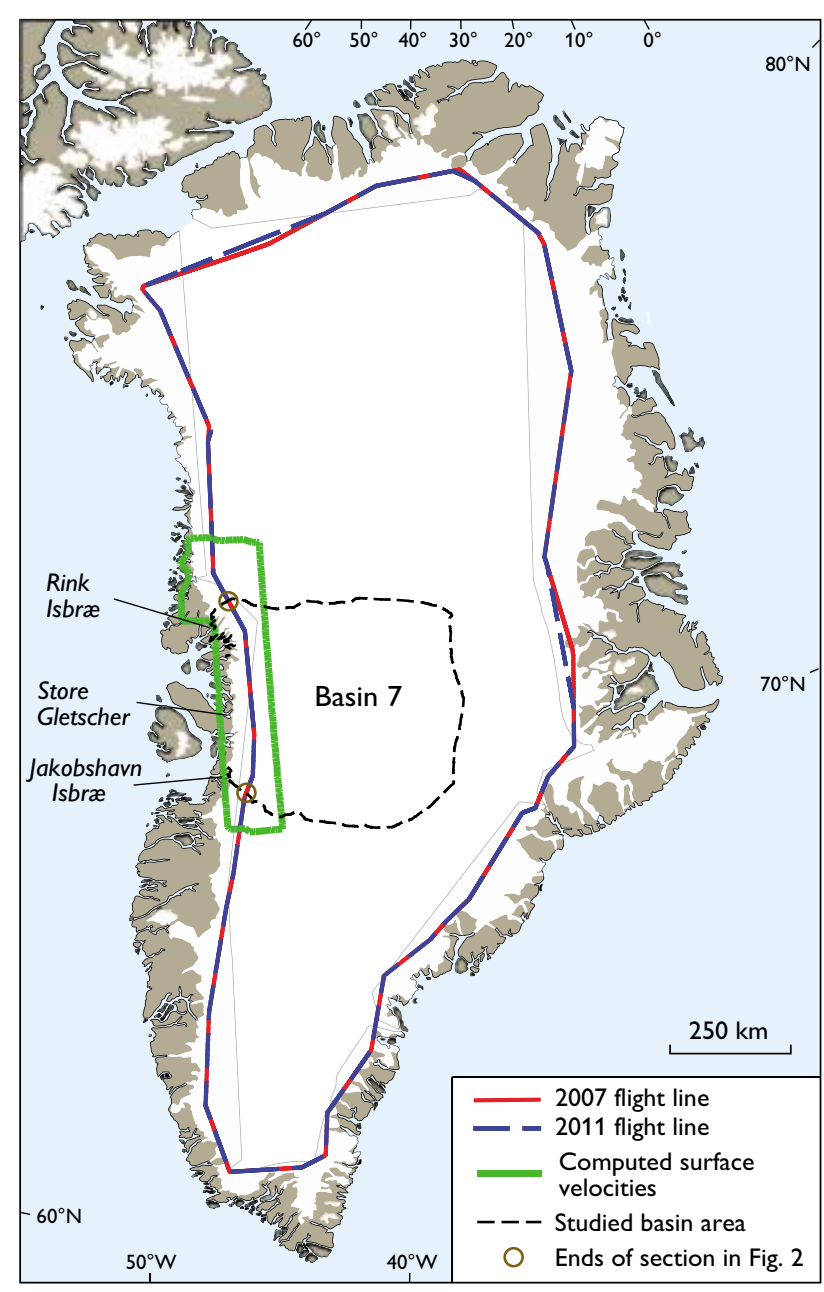

Fig. 1. Map of Greenland showing interpolated flight lines for 2007 and 2011, area of computed surface velocities for this study (Fig. 3) and the studied catchment area. 


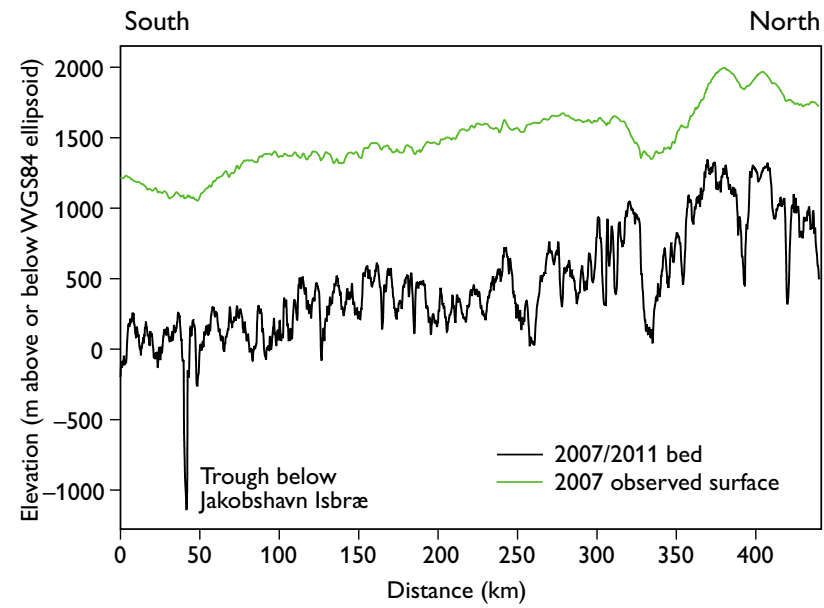

Fig. 2. South-to-north section of the studied basin along the 2007 and 2011 flight lines. For location see Fig. 1.

\section{Data and methods}

We estimate the solid ice discharge $(D)$ into the ocean according to the input-output method of Rignot \& Kanagaratnam (2006). First we quantify the mass flux $(F)$ discharging across a flux gate, upstream of the boundary between the ice sheet and the ocean (the grounding line), defined by the path of the PROMICE airborne ice-thickness surveys conducted in the summers 2007 and 2011 (Fig. 1). The elevation of this flux gate is c. $1500 \mathrm{~m}$ a.s.l. in Basin 7 (Figs 2, 3). The ice-surface and bed elevations determined by the airborne surveys were interpolated to $c .30 \mathrm{~m}$ spacing along the flux gate to resolve spatial variability in ice flow.

The flux $F$ at grid point $i$ is computed as $F_{i}=H_{i} \cdot L_{i} \cdot v_{i}$, where $H_{i}$ is the ice thickness, $L_{i}$ is the spacing along the flight line $(c .30 \mathrm{~m})$, and $v_{i}$ is the depth-averaged ice velocity component that is perpendicular to the flux gate. Ice surface velocities were derived by applying offset tracking to ALOS/ PALSAR synthetic aperture radar (SAR) data acquired between November 2009 and February 2010, using the SUSIE processing chain based on the commercial package GAMMA (Merryman Boncori et al. 2010; Ahlstrøm et al. 2011). Uncertainties associated with the ice velocities were estimated using the method of Mohr \& Merryman Boncori (2008) and are under $10 \%$ (Fig. 3). We assume a uniform vertical velocity profile, where ice-surface velocity is equivalent to depth-averaged velocity (i.e. 'plug flow'; Rignot \& Kanagaratnam 2006).

With the total basin flux $F\left(=\sum F_{i}\right)$ known, the grounding line discharge $(D)$ can be estimated by adding the spatially integrated surface mass balance (SMB) of the area downstream ('ds') of the flux gate: $D=F+S M B_{d s, r e f \text {, where }} \mathrm{SMB}_{d s, r e f}$ is a reference period (1961-1990) mean SMB field from the regional climate model MAR v3.2, forced at its boundaries by ECMWF reanalysis data and run at a spatial resolution of $25 \mathrm{~km}$ (Fettweis et al. 2013a). Similarly, the mass balance upstream of the flux gate (interior mass balance, IMB) can be computed by subtracting $F$ from the upstream spatially integrated SMB for the reference period: $I M B=S M B_{u s, r e f}-F$.

Quantification of $D$ allows us to estimate the total mass balance (TMB) of the drainage basin. The TMB value is calculated as $T M B=S M B_{t o t, y r}-D$, where $S M B_{t o t, y r}$ is the yearly SMB spatially integrated across the entire basin.

Estimated uncertainty $(\sigma b)$ on radar-derived bed elevation $b$ values is $80 \mathrm{~m}$ and estimated uncertainty $(\sigma s)$ on laser-derived surface elevation observations $(s)$ is $0.1 \mathrm{~m}$. Assuming errors in $b$ and $s$ are random, we take uncertainty in ice thickness $(\sigma H)$ as the sum in quadrature of the fractional uncertainties of $\sigma b$ and $\sigma s$ (e.g. Colgan et al. 2008). Uncertainty in flux $F$ at gridpoint $i\left(\sigma F_{i}\right)$ is similarly taken as the sum in quadrature of the fractional uncertainties of $\sigma H_{i}$ and $\sigma v_{i}$, where the latter term is the uncertainty in the annual

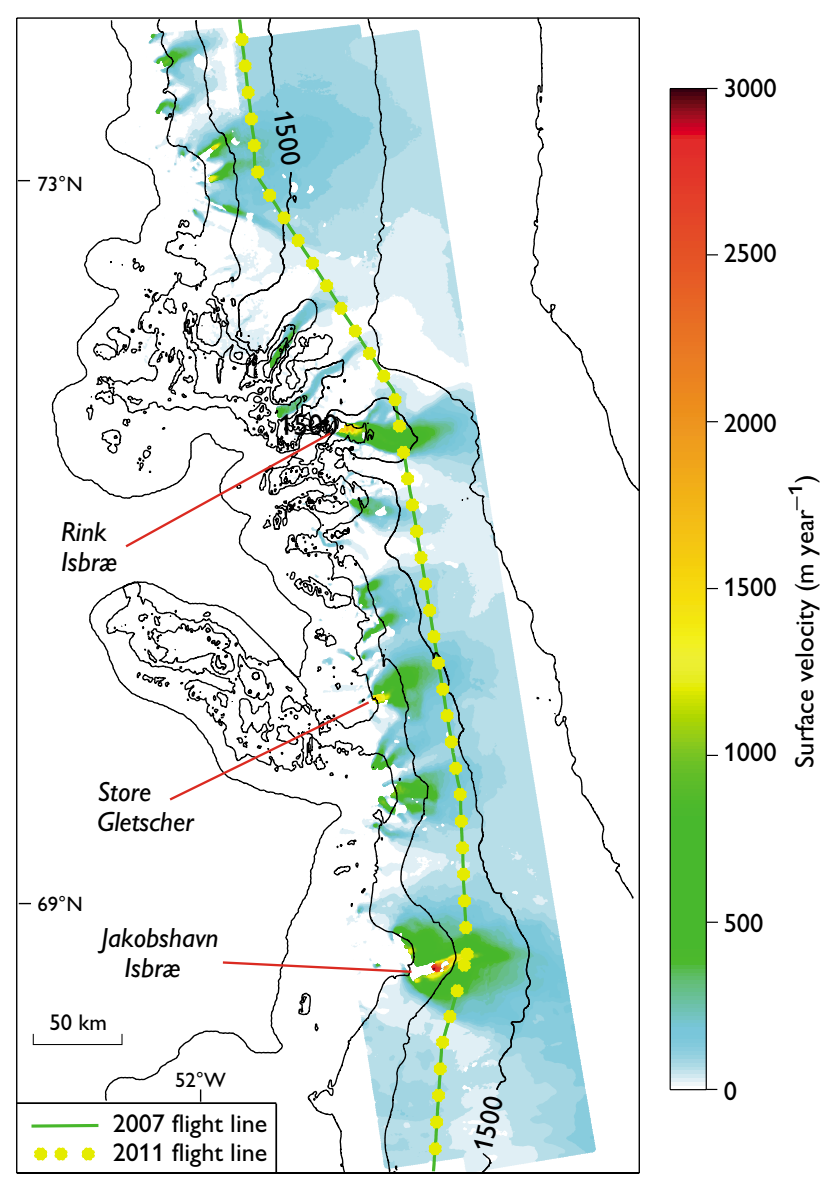

Fig. 3. Surface velocities derived from synthetic aperture radar (SAR) data for 2009-2010 used in this study. The contour lines are based on the digital elevation model of the Greenland ice mapping project (Howat $e t$ al. 2014). 
depth-averaged velocity at $i$. We assume no uncertainty in $L_{i}$. Uncertainty in the total flux $F$ in the basin is then $\sigma F=\sum \sigma F_{i}$. We take uncertainty in SMB to be $15 \%$ at basin scale (Fettweis et al. 2013a) and similarly propagate uncertainties in both $F$ and SMB as the sum in quadrature of fractional uncertainties when assessing the cumulative uncertainty $(\sigma D)$ associated with the grounding-line ice discharge. Uncertainties on TMB and IMB are developed analogously.

The thickness observations were carried out in summer, and we do not account for the difference between summer and winter ice velocities. However, at $c .1500 \mathrm{~m}$ a.s.l., we expect the difference between summer and winter ice velocities to be small ( $<2 \%$; Joughin et al. 2008).

\section{Results}

Both the upstream flux $(F)$ and downstream discharge $(D)$ in Basin 7 are within the uncertainty of their respective values in 2007 and 2011 (Table 1). Whereas we employ different airborne-derived, ice-geometry data for each year, the velocity field used is identical for the two years (winter 2009/2010 values), as is the surface mass-balance correction (1961-1990 values). The similar mass fluxes indicate that changes in ice geometry along the $c .1500 \mathrm{~m}$ contour were slight between 2007 and 2011.

Interior mass-balance values for both years are zero within the uncertainty, which is in good agreement with Zwally et al. (2011), who found a slight mass gain of $8 \mathrm{Gt} \mathrm{yr}^{-1}$ above $2000 \mathrm{~m}$ a.s.l.

The total mass-balance values are also, within uncertainty, similar for 2007 and 2011. Considering the $c .10 \mathrm{Gt} \mathrm{yr}^{-1}$ decrease in $D$, this suggests that yearly fluctuations in the dynamics of major tidewater outlet glaciers in Basin 7 are balanced by variations in surface mass balance. The mean total mass-balance value $\left(-30.5 \mathrm{Gt} \mathrm{yr}^{-1}\right)$ corresponds to a sea-level rise contribution of c. $0.08 \mathrm{~mm} \mathrm{yr}^{-1}$, and agrees within uncertainty with a satellite gravimetry-derived total mass-balance estimate of $-24 \pm 1 \mathrm{Gt} \mathrm{yr}^{-1}$ for Basin 7 over the 2004 to 2010 period (Colgan et al. 2014), and a 2007 total mass-balance value reported in Rignot et al. (2008) of $-36.7 \mathrm{Gt} \mathrm{yr}^{-1}$ for an analogous West Greenland basin. The 2007 value we present is more negative than a Basin 7 estimate of $-14 \pm 1 \mathrm{Gt} \mathrm{yr}^{-1}$ over the 2003 to 2007 period derived from satellite altimetry (Zwally et al. 2011). This latter study, however, preceded the 2007 to 2011 observation period, and may therefore reflect the less negative surface mass-balance regime prior to the observation period (Fettweis et al. 2013b).
Table 1. Mass fluxes in Gt per year

\begin{tabular}{ccccc}
\hline Year & $\begin{array}{c}\text { Upstream } \\
\text { flux (F) }\end{array}$ & $\begin{array}{c}\text { Ice } \\
\text { discharge (D) }\end{array}$ & $\begin{array}{c}\text { Interior } \\
\text { balance (IMB) }\end{array}$ & $\begin{array}{c}\text { Total mass } \\
\text { balance* }\end{array}$ \\
\hline 2007 & $79.5 \pm 6.1$ & $70.4 \pm 6.2$ & $-5.6 \pm 12.6$ & $-31.3 \pm 8.6$ \\
2011 & $69.7 \pm 5.3$ & $60.6 \pm 5.5$ & $-4.1 \pm 12.3$ & $-29.7 \pm 7.2$ \\
\hline
\end{tabular}

* Total mass balance $=\mathrm{SMB}_{\text {tot,yr }}-\mathrm{D}$

\section{Summary remarks}

Rignot \& Kanagaratnam (2006) invoked an assumption of negligible changes in ice geometry between their flux gates and the grounding line. As their flux gates are located at the $c .1000 \mathrm{~m}$ elevation contour, any dynamic thickening or thinning signals affect a relatively small proportion of the basin area. Given that the PROMICE flux gates are substantially farther inland from the grounding line, we are exploring approaches for explicitly correcting $D$ values for recent changes in ice geometry between the upstream flux gate and the downstream grounding line. This may be particularly relevant in highly dynamic areas, such as the Jakobshavn Isbræ area. A preliminary assessment of such a correction for Basin 7 suggests that the rate of change in downstream ice volume is equivalent to $c .25 \%$ of $D$, which would further decrease the total mass balance by up to $15 \mathrm{Gt} \mathrm{yr}^{-1}$. As more synthetic aperture radar data become available, we will improve the temporal coverage of the PROMICE ice-surface velocity product to annual resolution.

The plug-flow assumption adds a negative bias to the massloss estimates by assuming that all flow is caused by sliding at the bed, i.e., the surface speed is equal to the mean flow velocity of the ice column. This may be valid in the fast flowing coastal areas, but higher up on the ice sheet the assumption is less valid, where the surface velocity is a mix of sliding and deformation, and the vertically averaged flow speed can be as low as $80 \%$ of the observed surface speed.

In the PROMICE framework, this basin-scale mass-balance assessment will be extended to deliver basin-scale massbalance and ice-discharge estimates of the entire Greenland ice sheet over multiple observation years. This survey aims to improve portioning of mass loss at basin scale, contributing to improved sea-level rise projections for the Greenland ice sheet.

\section{Acknowledgments}

PROMICE is funded by the Danish Ministry of Climate, Energy and Building, and is operated by the Geological Survey of Denmark and Greenland. This paper is contribution number 38 of the Nordic Centre of Excellence SVALI, Stability and Variations of Arctic Land Ice, funded by the Nordic Top-level Research Initiative. 


\section{References}

Ahlstrøm, A. \& the PROMICE project team 2008: A new programme for monitoring the Greenland ice sheet mass loss. Geological Survey of Denmark and Greenland Bulletin 15, 61-64.

Ahlstrøm, A. et al. 2011: PROMICE 2007-2010. Final report for the establishment phase of the Programme for Monitoring of the Greenland Ice Sheet. Danmarks og Grønlands Geologiske Undersøgelse Rapport 2011/118, 178 pp.

Andersen, M.L. et al. 2010: Spatial and temporal melt variability at Helheim Glacier, East Greenland, and its effect on ice dynamics. Journal of Geophysical Research, Earth Surface 115, F04041.

Colgan, W., Davis, J. \& Sharp, M. 2008: Is the high-elevation region of Devon Ice Cap thickening? Journal of Glaciology 54, 428-436.

Colgan, W., Abdalati, W., Citterio, M., Csatho, B., Fettweis, X., Luthcke, S., Moholdt, G. \& Stober, M. 2014: Hybrid inventory, gravimetry and altimetry (HIGA) mass balance product for Greenland and the Canadian Arctic. The Cryosphere Discussions 8, 537-580.

Enderlin, E.M., Howat, I.M., Jeong, S., Noh, M.-J., van Angelen, J.H. \& van den Broeke, M.R. 2014: An improved mass budget for the Greenland ice sheet. Geophyscial Research Letters 41, 866-872.

Fettweis, X., Franco, B., Tedesco, M., van Angelen, J.H., Lenaerts, J.T.M., van den Broeke, M.R. \& Gallee, H. 2013a: Estimating the Greenland ice sheet surface mass balance contribution to future sea level rise using the regional atmospheric climate model MAR. The Cryosphere 7, 469-489.

Fettweis, X., Hanna, E., Lang, C., Belleflamme, A., Erpicum, M. \& Gallée, H. 2013b: Brief communication: Important role of the mid-tropospheric atmospheric circulation in the recent surface melt increase over the Greenland ice sheet. The Cryosphere 7, 241-248.

Howat, I.M., Negrete, A. \& Smith, B. 2014: The Greenland ice mapping project (GIMP) land classification and surface elevation datasets. The Cryosphere Discussions 8, 453-478.

Merryman Boncori, J.P., Dall, J., Ahlstrøm, A.P \& Andersen, S.B. 2010: Validation and operational measurements with SUSIE - a SAR icemotion processing chain developed within PROMICE (Programme for the monitoring of the Greenland ice sheet). In: Lacoste-Francis, H. (ed.): Proceedings of the ESA Living Planet Symposium, Bergen, Norway (ESA SP-686) Noordwijk: ESA Communications ESTEC.
Mohr, J.J. \& Merryman Boncori, J.P. 2008: An error prediction framework for interferometric SAR data. IEEE Transactions on Geoscience and Remote Sensing 46, 1600-1613.

Nick, F.M., Vieli, A., Howat, I.M. \& Joughin, I. 2009: Large-scale changes in Greenland outlet glacier dynamics triggered at the terminus. Nature Geoscience 2, 110-114.

Nick, F.M., Vieli, A., Andersen, M.L., Joughin, I., Payne, A.J., Edwards, T.L., Pattyn, F. \& van de Wal, R.S.W. 2013: Future sea-level rise from Greenland's main outlet glaciers in a warming climate. Nature 497, 235-238.

Rignot, E. \& Kanagaratnam, P. 2006: Changes in the velocity structure of the Greenland ice sheet. Science 311, 986-990.

Rignot, E., Box, J.E., Burgess, E. \& Hanna, E. 2008: Mass balance of the Greenland ice sheet from 1958 to 2007. Geophysical Research Letters 35, L20502.

Shepherd, A. et al. 2012: A reconciled estimate of ice-sheet mass balance. Science 338, 1183-1189.

Thomas, R., Frederick, E., Krabill, W., Manizade,S. \& Martin, C. 2006: Progressive increase in ice loss from Greenland. Geophysical Research Letters 33, L10503, doi:10.1029/2006GL026075.

Van den Broeke, M., Bamber, J., Ettema, J., Rignot, E., Schrama, E. \& van den Berg, W.J., van Meijgaard, E., Velicogna, I. \& Wouters, B. 2009: Partitioning recent Greenland mass loss. Science 326, 984-986.

Van der Veen, C.J., Plummer, J.C. \& Stearns, L.A. 2011: Controls on the recent speed-up of Jakobshavn Isbræ, West Greenland. Journal of Glaciology 57, 770-782.

Zwally, H., Abdalati, W., Herring, T., Larson, K., Saba, J. \& Steffen, K. 2002: Surface melt-induced acceleration of Greenland ice-sheet flow. Science 297, 218-222.

Zwally, H., Giovinetto, M., Beckley, M. \& Saba, J. 2012: Antarctic and Greenland drainage systems, NASA, Goddard Space Flight Center, Cryospheric Sciences Laboratory. http://icesat4.gsfc.nasa.gov/cryo_ data/ant_grn_drainage_systems.php.

Zwally, H. J. et al. 2011: Greenland ice sheet mass balance: distribution of increased mass loss with climate warming; 2003-07 versus 1992 2002. Journal of Glaciology 57, 88-102.

\footnotetext{
Authors' addresses

M.L.A., S.B.A., W.C., A.P.A., M.C., J.E.B., D.v.A. \& R.S.F., Geological Survey of Denmark and Greenland, Øster Voldgade 10 , DK-1350 Copenhagen K,

Denmark.E-mail:mola@geus.dk

L.S., H.S., S.S.K. \& R.F., DTU Space, DK-2800 Lyngby, Denmark.

X.F., Department of Geography, University of Liège, 4000 Liège, Belgium.

J.P.M.B., Istituto Nazionale di Geofisica e Vulcanologia, 00142 Rome, Italy.
} 